Biochimica et Biophysica Acta, 621 (1980) 104-116

(C) Elsevier/North-Holland Biomedical Press

BBA 38340

\title{
ISOLATION AND PARTIAL CHARACTERIZATION OF RAT GASTRIC MUCOUS GLYCOPROTEIN
}

\author{
RITA SPEE-BRAND, GER J.A.M. STROUS and MEBIUS F. KRAMER
}

Department of Histology and Cell Biology, State University of Utrecht, School of Medicine, Nic. Beetsstraat 22, 3511 HG Utrecht (The Netherlands)

(Received July 27th, 1979)

Key words: Glycoprotein analysis; Carbohydrate composition; (Rat gastric mucus)

\section{Summary}

Mucus glycoproteins from the rat stomach were characterized after their isolation from homogenates of the superficial gastric mucosa by equilibrium centrifugation in $\mathrm{CsCl}$ density gradients. Water-soluble as well as water-insoluble glycoproteins were studied. The latter were solubilized by 2-mercaptoethanol reduction of the homogenate. From both homogenate fractions the same two glycoproteins 1 and 2 were purified, glycoprotein 1 being present in considerably higher amount than glycoprotein 2 . Their respective buoyant densities in a $\mathrm{CsCl}$ gradient were $1.47-1.50 \mathrm{~g} / \mathrm{ml}$ and $1.56-1.58 \mathrm{~g} / \mathrm{ml}$. The two glycoproteins expressed slight differences in gel electrophoresis and gel filtration. The results from column chromatographic comparisons between reduced and unreduced glycoproteins indicated strongly that both glycoproteins 1 and 2 were built from subunits kept together by S-S bonds. The $s_{20, w}$ values of the reduced glycoproteins 1 and 2 were $15.7 \mathrm{~S}$ and $11.6 \mathrm{~S}$. Glycoprotein 1 contained $5 \%$ protein, $70 \%$ carbohydrate and $1-2 \%$ sulphate, whereas these percentages for glycoprotein 2 were $10 \%$ protein, $65 \%$ carbohydrate and $10 \%$ sulphate. The molar proportions of the main sugar components galactose, fucose, glucosamine and galactosamine were $4: 2: 4: 1$ (glycoprotein 1 ) and $3: 2: 3: 1$ (glycoprotein 2). Blood-group activity A was expressed by glycoprotein 1 , whereas glycoprotein 2 showed mainly blood-group activity $\mathrm{Le}^{\mathrm{b}}$, some B activity and also some A activity, but to a lesser extent than glycoprotein 1 .

\section{Introduction}

The epithelium of the stomach is covered by a layer of protecting mucus, which is synthesized by the gastric epithelial cells. Much attention has been 
given to the physicochemical characterization of the glycoproteins that constitute the mucus layer in the porcine [1], the canine [2,3] and the human stomach [4]. Additionally several aspects of glycoprotein synthesis have been studied. Previous reports from this laboratory dealt with the intracellular transport of rat gastric epithelial glycoproteins [5] and with the location and characteristics of some glycosyltransferases involved [6]. For further investigations on this subject a biochemical analysis of the secretory glycoproteins was needed, and this is described in the present paper.

The analyzed glycoproteins were derived from homogenized scrapings of the superficial layer of gastric mucosa. Since these glycoproteins contain predominantly carbohydrate $(70-80 \% \mathrm{w} / \mathrm{w})$ and little protein $(10-20 \% \mathrm{w} / \mathrm{w})$, their buoyant density is much higher than that of non-glycosylated proteins. For this reason they can be almost completely separated from non-covalently bound protein by equilibrium centrifugation in density gradients of highly concentrated cesium salt solutions. This method was used successfully to isolate mucous glycoproteins from pig gastric mucosa [1], from human ovarian cyst fluids [7], from sputum [8] and from cervical mucus [9]. In the experiments described in this paper gastric mucous glycoproteins from rat were isolated on cesium chloride gradients.

\section{Methods}

Preparation of gastric mucosa homogenate fractions. Wistar rats $(150-200 \mathrm{~g}$ body weight) were fasted for $24 \mathrm{~h}$ and killed by decapitation. Stomachs were

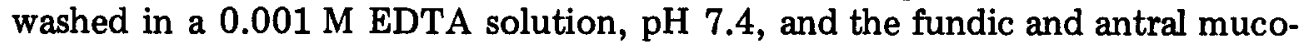
sae were scraped superficially with a razor blade. Microscopic examination of the scraped stomach wall revealed that only surface and pit mucous cells and adhering mucous were removed. The following procedures were conducted at $4^{\circ} \mathrm{C}$. Scrapings were collected in $0.001 \mathrm{M}$ EDTA and homogenized with a Polytron P CU-2 tissue homogenizer. The homogenate was centrifuged at $1700 \times g$ for $20 \mathrm{~min}$ to remove nuclei, cell debris and undissolved mucus. The supernatant was designated as homogenate fraction $\mathrm{I}$. The pellet was again homogenized after addition of an equal volume of $0.001 \mathrm{M}$ EDTA. Subsequently 2-mercaptoethanol was added to $0.5 \mathrm{M}$ concentration and after mixing the suspension was allowed to stand for $30 \mathrm{~min}$ at $37^{\circ} \mathrm{C}$, after which it was centrifuged $(1700 \times \mathrm{g}$, $20 \mathrm{~min}$ ). This supernatant was designated as homogenate fraction II. Fractions I, II and the remaining pellet, which was discarded, contained $20-30 \%, 60-$ $70 \%$ and $10-15 \%$, respectively, of the total hexose in the original mucosa homogenate. If not used immediately, fractions I and II were stored at $-20^{\circ} \mathrm{C}$.

$\mathrm{CsCl}$ equilibrium centrifugation. The method described by Starkey et al. [1] was used. $\mathrm{CsCl}$ (suprapure) was from Merck. The starting density of the $\mathrm{CsCl}$ solution was $1.42 \mathrm{~g} / \mathrm{ml}(40 \% \mathrm{w} / \mathrm{w} \mathrm{CsCl} / \mathrm{sample})$. Protein concentration in the samples was $2-5 \mathrm{mg} / \mathrm{ml}$. After centrifugation at $150000 \times \mathrm{g}$ for $60 \mathrm{~h}$ each gradient was eluted into $0.25 \mathrm{ml}$ fractions. The density of the fractions, determined by weighing a $50 \mu \mathrm{l}$ sample, increased linearly from the top $(1.22 \mathrm{~g} / \mathrm{ml})$ to the bottom $(1.62 \mathrm{~g} / \mathrm{ml})$ of the tube. To remove $\mathrm{CsCl}$, fractions were dialyzed extensively against water, or precipitated with ethanol. For the latter purpose each fraction was mixed with $1 \mathrm{ml}$ water and $0.125 \mathrm{ml} 2 \mathrm{M}$ potassium acetate, 
pH 5.0. Then $7.5 \mathrm{ml}$ cold ethanol (96\%) were added and precipitation was allowed to take place at $-20^{\circ} \mathrm{C}$ overnight. The precipitates were centrifuged, washed twice with ethanol, lyophilized and dissolved in distilled water.

Gel electrophoresis. Preparation of $2 \% \mathrm{w} / \mathrm{v}$ polyacrylamide- $0.5 \% \mathrm{w} / \mathrm{v}$ agarose gels and electrophoresis essentially were carried out as described by Peacock and Dingman [10]. The buffer solution contained $0.1 \% \mathrm{w} / \mathrm{v}$ sodium dodecyl sulfate, Prior to electrophoresis samples were reduced in $0.01 \mathrm{M}$ 2-mercaptoethanol for $30 \mathrm{~min}$ at $37^{\circ} \mathrm{C}$ and gels were pre-electrophorized for $1 \mathrm{~h}$ in buffer supplemented with $0.01 \mathrm{M} 2$-mercaptoethanol. Electrophoresis was performed at $100 \mathrm{~V}$ and $10 \mathrm{~mA}$ per gel for about $2 \mathrm{~h}$. Electrophoresis on $7-15 \% \mathrm{w} / \mathrm{v}$ polyacrylamide gradient gels in the presence of sodium dodecyl sulfate was performed according to Laemmli [11]. Gels were stained with periodic acid-Schiff reagent [12], after removal of the sodium dodecyl sulfate with isopropanol, or with Coomassie blue.

Column chromatography. Homogenate fraction I and glycoproteins purified by $\mathrm{CsCl}$ gradient centrifugation were applied to a column of Sepharose $4 \mathrm{~B} \mathrm{CL}$ (Pharmacia), $90 \times 1.5 \mathrm{~cm}$. The gel was equilibrated and eluted with an aqueous solution of $0.5 \mathrm{M} \mathrm{NaCl} / 0.05 \mathrm{M}$ Tris-HCl/0.001 M EDTA, $\mathrm{pH} 7.4$. When reduced glycoproteins were eluted, the elution buffer was supplemented with $0.01 \mathrm{M}$ 2-mercaptoethanol.

Analytical ultracentrifugation. Sedimentation velocity analyses were conducted in a Spinco Model E analytical ultracentrifuge (Beckman) equipped with a monochromator and a photoelectrical scanner. Schlieren optics in combination with single sector cells were used for glycoprotein concentration above $100 \mu \mathrm{g} / \mathrm{ml}$. When the concentration was lower, glycoproteins were stained with periodic acid-Schiff reagent, as described by McGuckin and McKenzie [13], prior to the experiment. In this case double sector cells were used these being scanned at $555 \mathrm{~nm}$. Rotor speed was $60000 \mathrm{rev} . / \mathrm{min}$. The buffer solution used was $0.18 \mathrm{M} \mathrm{KCl} / 0.02 \mathrm{M} \mathrm{KAc}, \mathrm{pH} 5.5$. Sedimentation coefficients were corrected for buffer solution density and viscosity.

Reduction and alkylation of glycoproteins 1 and 2. For reduction and alkylation of the glycoproteins the method of Press et al. [14] was used. Glycoprotein $(1 \mathrm{mg} / \mathrm{ml})$ was dissolved in a solution of $6 \mathrm{M}$ guanidinium chloride in $0.5 \mathrm{M}$ Tris- $\mathrm{HCl}, \mathrm{pH}$ 8.5. After addition of 2-mercaptoethanol to a concentration of $0.5 \mathrm{M}$, the sample was reduced for $5 \mathrm{~h}$ at $25^{\circ} \mathrm{C}$. Alkylation was achieved by adding an equivalent volume of $3 \mathrm{M}$ iodoacetic acid in $0.5 \mathrm{M}$ Tris- $\mathrm{HCl}, \mathrm{pH} 8.5$, and keeping the sample in the dark for $30 \mathrm{~min}$ at $25^{\circ} \mathrm{C}$. $\mathrm{pH}$ was maintained at 8.5 with addition of $1.0 \mathrm{M} \mathrm{NaOH}$. Subsequently the samples were dialyzed against water and lyophilized.

Treatment of the glycoproteins by trypsin or pronase. Pronase $\mathrm{E}$ and trypsin (from bovine pancreas, twice crystallized) were from Merck and Sigma, respectively. The proteolytic digestion was carried out during $72 \mathrm{~h}$ at $37^{\circ} \mathrm{C}$, as described by Scawen and Allen [15].

Analytical procedures. Total protein was measured by the method of Lowry et al. [16], with bovine serum albumin as a standard.

Total hexose was assayed by the orcinol method of Francois et al. [17] with a mixture of galactose and fucose as a standard. (This standard was based on the relative amounts of galactose and fucose in the glycorpoteins as determined 
by gas-liquid chromatography. Thus, for glycoproteins 1 and 2 the galactose : fucose ratio was $2: 1$ and $3: 2$, respectively.)

Sialic acid was quantified by the thiobarbituric acid method [18] after hydrolysis of the samples in $0.1 \mathrm{M} \mathrm{H}_{2} \mathrm{SO}_{4}$ at $80^{\circ} \mathrm{C}$ for $1 \mathrm{~h}$.

Sulphate was determined by the turbidimetric method of Dodgson and Price [19] as modified by Starkey et al. [1].

Quantitative analysis of the sugars by gas-liquid chromatography was performed as described by Kamerlingh et al. [20]. Samples were hydrolyzed in methanolic $1 \mathrm{M} \mathrm{HCl}$ for $24 \mathrm{~h}$ at $85^{\circ} \mathrm{C}$.

Amino acid composition was assayed with a Beckman Multichrom analyzer and a T.S.M. (Technicon) analyzer. The results were in good agreement with each other. Glycoproteins were hydrolyzed in $6 \mathrm{M} \mathrm{HCl}$ at $110^{\circ} \mathrm{C}$ for $24 \mathrm{~h}$. Values of threonine and serine were multiplied by 1.05 and 1.10 , respectively, to correct for loss during hydrolysis.

Hemagglutination inhibition assay. The method of Boorman and Dodd [21] was used. Human $\mathrm{A}, \mathrm{B}, \mathrm{Le}^{\mathrm{b}+}$ and $\mathrm{Le}^{\mathrm{b}-}$ erythrocytes were used as test cells. The titer of the anti-A and anti-B sera was 128 , that of the anti-Le ${ }^{b}$ serum was 8 . To test A and B blood-group activity, $10 \mu \mathrm{l}$ glycoprotein solution $(0.1 \% \mathrm{w} / \mathrm{v})$ in physiological salt were incubated with $10 \mu \mathrm{l}$ test serum on slides, $20^{\circ} \mathrm{C}$ for 10 min. Then $20 \mu \mathrm{l} 10 \%$ red cell suspension were added. Agglutination was read microscopically after $10 \mathrm{~min}$. When testing $\mathrm{Le}^{\mathrm{b}}$ activity $40 \mu \mathrm{l}$ glycoprotein solution $(0.3 \% \mathrm{w} / \mathrm{v})$ were incubated with $40 \mu \mathrm{l}$ anti-Le ${ }^{\mathrm{b}}$ serum in tubes, for 30 min at $4^{\circ} \mathrm{C}$. Then $40 \mu \mathrm{l}$ of a $5 \% \mathrm{Le}^{\mathrm{b}}$ red cell suspension were added and the incubation was continued for $30 \mathrm{~min}$ at $4^{\circ} \mathrm{C}$. Cells were centrifuged for $1 \mathrm{~min}$ at $1000 \mathrm{rev} . / \mathrm{min}$ and agglutination was checked by eye, during careful resuspension of the red cell pellet.

\section{Results}

\section{CsCl equilibrium centrifugation}

The water-soluble fraction of gastric mucosal homogenate (fraction I) and the reduced homogenate fraction (fraction II) were centrifuged to equilibrium in a $\mathrm{CsCl}$ density gradient. Typical distributions of hexose and protein containing materials from both fractions are shown in Fig. 1. Nearly all hexosecontaining material was present at the higher densities, with fractions I and II showing a prominent peak at densities 1.47 and $1.50 \mathrm{~g} / \mathrm{ml}$, respectively. Fraction I also contained a substantial amount of carbohydrate at the bottom of the gradient, which was absent from the gradient of fraction II. This material had a high absorption at $280 \mathrm{~nm}$ but very little protein was present. Sugar analysis revealed that it contained much glucose, probably derived from glycogen. Very little protein was present in the hexose peak of fraction II, while none could be detected in the hexose peak of fraction I. The latter probably resulted from the much lower amount of material in this peak, compared to that in fraction II, as judged by its hexose content. Considerable protein was present in the top fractions of both gradients. Precipitated material was floating at the gradient surfaces, containing much protein but little hexose. The dry weight material of the original sample was distributed over the gradients as follows: densities $1.62-1.40 \mathrm{~g} / \mathrm{ml}, 5-15 \%$; densities $1.40-1.22 \mathrm{~g} / \mathrm{ml}, 40-50 \%$; 


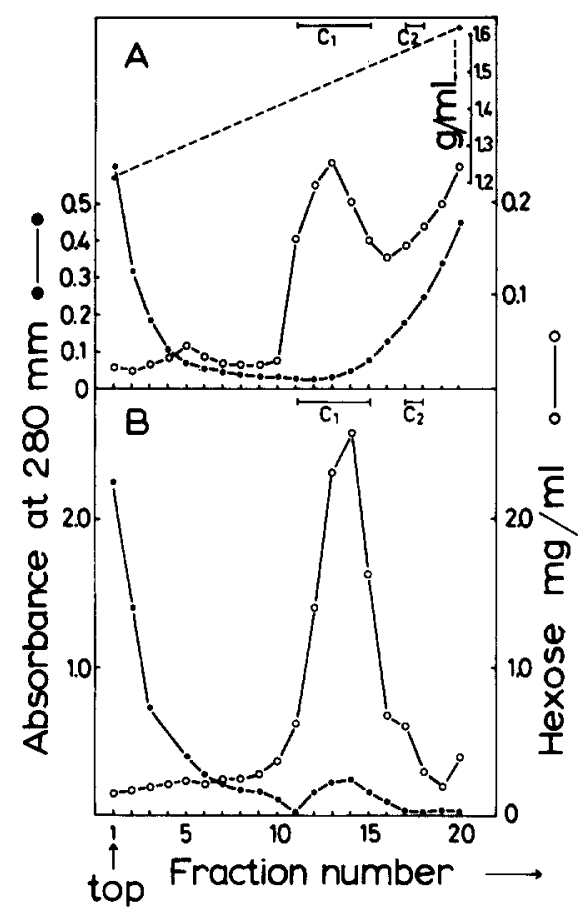

Fig. 1. Fractionation of gastric mucosal homogenate on a $\mathrm{CsCl}$ density gradient: $\mathrm{A}$, water-soluble homogenate fraction I: B, reduced homogenate fraction II. The starting density of the $\mathrm{CsCl}$ solution was $1.42 \mathrm{~g} / \mathrm{ml}$.

and the precipitated material at the top, 40-55\%. From the high carbohydrate content relative to the protein amount in the gradient fractions with densities greater than $1.40 \mathrm{~g} / \mathrm{ml}$ it was concluded that these fractions contained the mucous glycoproteins.

\section{Gel electrophoresis}

After removal of $\mathrm{CsCl}$ from the high density gradient fractions, electrophoresis was performed using $2 \%$ polyacrylamide- $0.5 \%$ agarose gels. Similar results were obtained for homogenate fractions I and II. The periodic acid-Schiff stained migration patterns of the pooled and the individual gradient fractions 11-20 (from homogenate fraction II) are successively shown in Figs. $2 a$ and $b$. The gels from fractions 17 and 18 contained a component which migrated more quickly than that in fractions $11-16$. The transition between the migration distances of the components in fractions 11-18 was not gradual. This could be demonstrated when fractions 16-20 were pooled before electrophoresis (Fig. 2c). In this pool the fast and the slow migrating components were present in about equal amounts. The periodic acid-Schiff positive material was clearly separated into two components having a slightly different migration rate. The same relative difference in migration rate was retained after treatment of the samples with trypsin or pronase and was most clear after reduction and subsequent alkylation of the components (Fig. $2 \mathrm{~d}$ ). When aliquots of samples 11-18 were standardized to an equal amount of hexose, the slowly migrating 


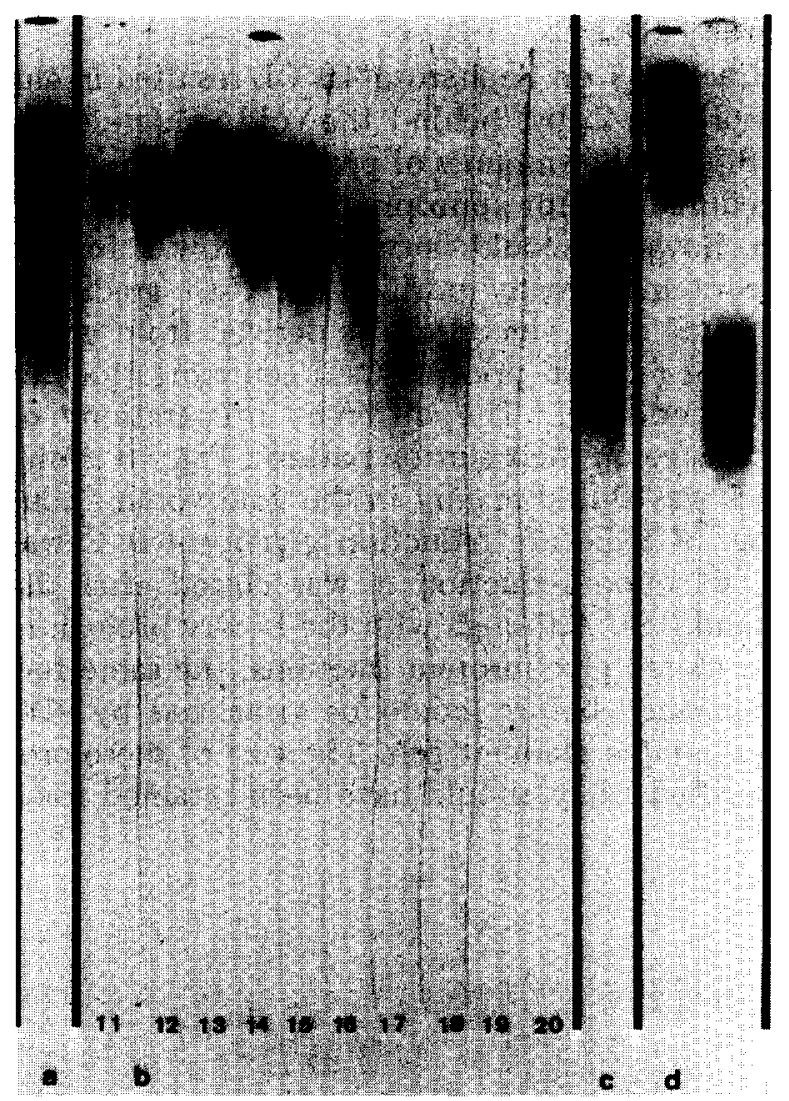

Fig. 2. Polyacrylamide-agarose gel electrophoresis of the pooled and the individual high-density $\mathrm{CsCl}$ gradient fractions from homogenate fraction II. Electrophoresis was performed as described in the Methods section. 100-200 $\mathrm{mg}$ mucous glycoprotein were applied per gel. In the gels of fractions 11-20, the amount of glycoprotein was directly proportional to that in the original CsCl fraction. a, Pool of the fractions 11-20; b, fractions 11-20 from left to right, respectively; c, pool of the fractions 16-20; d, reduced and alkylated pool of fractions $11-15$ (left) and 17-18 (right).

component was more intensely stained by periodic acid-Schiff reagent than the more quickly moving component. So the broad periodic acid-Schiff-positive spot on the gel in Fig. 2a actually represented a major and a minor glycoprotein component of slightly different character. The glycoproteins were stained very weakly by Coomassie blue. With this reagent no other protein could be detected in the gels of fractions 11-20. When these fractions were examined on $7-15 \%$ polyacrylamide gradient gels in the presence of sodium dodecyl sulfate, a few faint protein bands were visible which were somewhat more prominent when the glycoproteins were sampled from unreduced material. With methylene blue nucleic acids were shown to be present in fractions 19 and 20.

Consequently, further characterization of the two glycoprotein components was performed on pools of $\mathrm{CsCl}$ gradient fractions 10-15 (glycoprotein 1) and fractions 17-18 (glycoprotein 2). 


\section{Column chromatography}

Gel filtration of homogenate fraction I on Sepharose 4B CL resulted in elution of glycoprotein 1 and glycoprotein 2 just behind the void volume (indicated by the arrows in Fig. 3A). Since large amounts of protein were present in these eluted fractions, this procedure was not appropriate for purification of the glycoproteins. Gel filtration, however, could be used to show a further difference between those glycoproteins already purified on $\mathrm{CsCl}$ gradients. We compared the elution patterns of both glycoproteins derived from either homogenate fraction I (unreduced or reduced prior to $\mathrm{CsCl}$ centrifugation) or from the reduced homogenate fraction II. The different preparations of reduced glycoproteins had no influence on their elution pattern. Fig. 3B shows that the unreduced glycoprotein 1 was eluted mainly in the void volume, but was retained after reduction (Fig. 3C). Before reduction glycoprotein 2 was retained by Sepharose $4 \mathrm{~B} \mathrm{CL}$, but upon reduction it was eluted after the reduced glycoprotein 1 (Fig. 3D and $3 \mathrm{E}$ ). Although with the Lowry procedure no protein was detectable in the eluted glycoprotein fractions, the same few minor protein bands, already mentioned before, could be visualized by SDS electrophoresis on 7-15\% polyacrylamide gradient gels. The size of these proteins was so small that, when purified, they should have been retained for a longer time by Sepharose 4B CL.

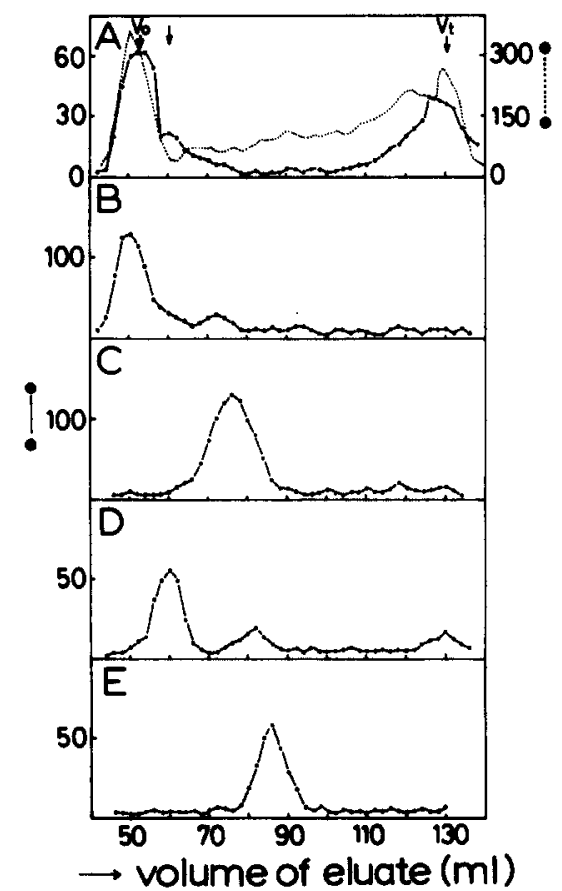

Fig. 3. Gel filtration of the water-soluble homogenate fraction I and purfied glycoproteins 1 and 2 on Sepharose 4B CL. The fraction size was $2 \mathrm{ml}$. The columns were run at $4^{\circ} \mathrm{C}$. The void volume was determined by eluting Blue Dextran 2000. A, Homogenate fraction I, most central arrow : volume where glycoprotein 2 was eluted; B, unreduced glycoprotein $1 ; C$, reduced glycoprotein $1 ; D$, unreduced glycoprotein 2 ; $\mathrm{E}$, reduced glycoprotein $2 . \bullet \mu \mathrm{g}$ hexose $/ \mathrm{ml} ; \cdots \cdots, \mu \mathrm{g}$ protein $/ \mathrm{ml}$. 
Analytical ultracentrifugation

The sedimentation velocities of the reduced glycoproteins 1 and 2 were studied at several concentrations (Fig. 4). As the amount of purified glycoprotein was scarce, these concentrations were low. Prior to the experiment, molecules were stained with periodic acid-Schiff when their concentration was lower than $100 \mu \mathrm{g} / \mathrm{ml}$ (glycoprotein 1). Thus the method of Jabbal et al. [22] was followed. Apparently no change in sedimentation velocity of the glycoproteins occurred after the staining procedure, as can be concluded from Fig. 4. All $s_{20, w}$ values, for stained as well as for unstained samples, showed a linear correlation with concentration for both glycoproteins. The $s_{20, w}^{0}$ values were $15.7 \mathrm{~S}$ and $11.6 \mathrm{~S}$ for glycoproteins 1 and 2 respectively. No precise $s_{20, w}^{0}$ value could be determined for the unreduced glycoproteins, as there was no linear correlation between the $s_{20, \mathrm{w}}$ values and corresponding concentrations. The $s_{20, \mathrm{w}}$ values increased with increasing concentration. These findings probably resulted from a variable degree of aggregation of the molecules.

\section{Chemical composition}

The chemical composition of the glycoproteins 1 and 2, from both homogenate fractions I and II, is shown in Table I. The main sugars present were galactose, fucose, glucosamine and galactosamine, with molar proportions $4: 2: 4: 1$ in glycoprotein 1 and $3: 2: 3: 1$ in glycoprotein 2 . In both cases these sugars accounted for more than $65 \%$ of the dry weight material. Only very little sialic acid was measured. The amount of fucose in glycoprotein 2 was noticeably higher than in glycoprotein 1 . Besides, glycoprotein 2 contained more protein and much more sulfate. The latter result is clearly demonstrated in Fig. 5, which shows the sulfate/hexose ratio together with the hexose content in the high density fractions of a $\mathrm{CsCl}$ gradient of homogenate fraction II.

Table II presents the amino acid composition. Threonine and serine were present in high amounts, just as aspartic acid, glutamic acid and glycine. Cyste-
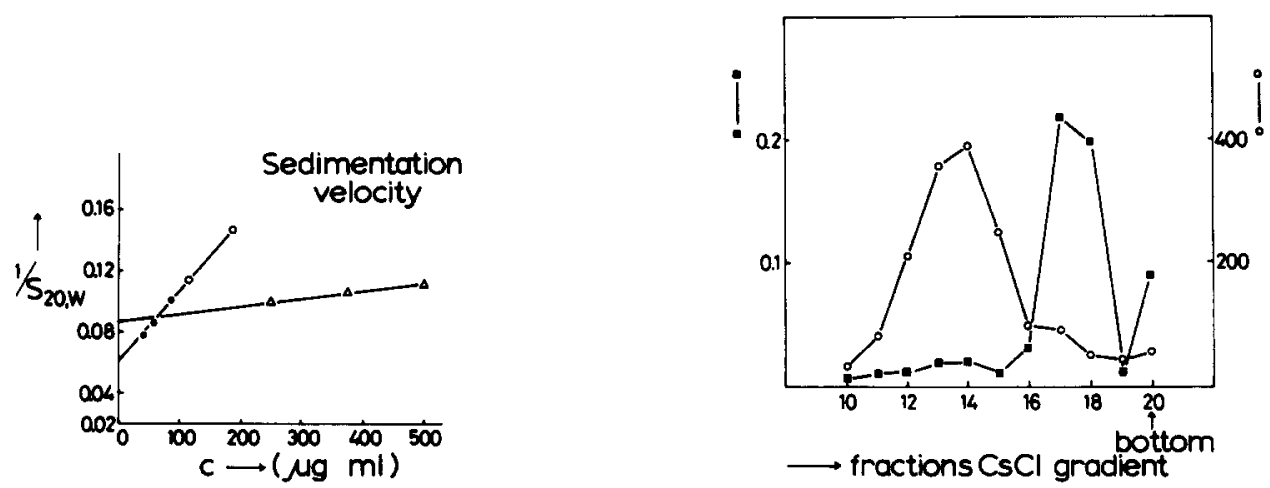

Fig. 4. Analytical ultracentrifugation of reduced glycoproteins 1 and 2 . Sedimentation velocity analyses were performed as described in Methods. $\odot$, Values obtained for glycoprotein 1, Samples with glycoprotein concentrations $<100 \mu \mathrm{g} / \mathrm{ml}(\bullet)$ were stained with periodic acid-Schiff; $\Delta$, values obtained for glycoprotein 2.

Fig. 5. Sulfate : hexose ratio in the high-density fractions of a $\mathrm{CsCl}$ gradient of homogenate fraction II. $\bullet$, sulfate $/$ hexose $\mathrm{mg} / \mathrm{ml}$; $O$, hexose $\mu \mathrm{g} /$ gradient fraction. 
TABLE I

CHEMICAL COMPOSITION OF GLYCOPROTEINS 1 AND 2

The analytical techniques used are described in the Methods section. Protein values were calculated by adding up the amounts of individual amino acids, obtained from analysis. The results are expressed as weight percentages of freeze-dried material and are averages of three of five experiments.

\begin{tabular}{|c|c|c|c|c|}
\hline \multirow[b]{2}{*}{ Gly coprotein } & \multicolumn{2}{|c|}{ Homogenate fraction I } & \multicolumn{2}{|c|}{ Homogenate fraction II } \\
\hline & 1 & 2 & 1 & 2 \\
\hline Galactose & 24.72 & 23.10 & 26.16 & 22.01 \\
\hline Fucose & 12.36 & 15.78 & 14.13 & 15.16 \\
\hline Glucosamine & 27.38 & 21.20 & 28.99 & 18.90 \\
\hline Galactosamine & 6.68 & 6.78 & 7.07 & 6.07 \\
\hline Sialic acid & 0.20 & 0.21 & 0.17 & 0.19 \\
\hline Protein & 5.03 & 10.21 & 4.90 & 9.61 \\
\hline Sulfate & 1.85 & 9.40 & 1.55 & 11.25 \\
\hline Total recovery & 78.22 & 86.68 & 82.97 & 83.19 \\
\hline
\end{tabular}

TABLE II

\section{AMINO ACID COMPOSITION OF GLYCOPROTEINS 1 AND 2}

The samples were S-carboxymethylated in $6 \mathrm{M}$ guanidinium hydrochloride by the method of Press et al. [14]. Reduction was carried out with $0.5 \mathrm{M} 2$-mercaptoethanol. The amount of each amino acid is expressed as the number of residues per 100 total amino acid residues. The results are average values from three experiments.

\begin{tabular}{|c|c|c|c|c|}
\hline \multirow[b]{2}{*}{ Glycoprotein } & \multicolumn{2}{|c|}{ Homogenate fraction I } & \multicolumn{2}{|c|}{ Homogenate fraction II } \\
\hline & 1 & 2 & 1 & 2 \\
\hline Asp & 9.45 & 8.40 & 8.18 & 6.81 \\
\hline Thr & 13.10 & 15.36 & 16.95 & 19.44 \\
\hline Ser & 11.82 & 14.57 & 15.97 & 18.81 \\
\hline Glu & 13.24 & 10.74 & 12.44 & 10.70 \\
\hline Pro & $\mathbf{3 . 5 3}$ & 3.76 & 3.21 & 4.14 \\
\hline Gly & 11.23 & 14.47 & 11.82 & 14.70 \\
\hline Ala & 5.42 & 6.10 & 4.12 & 3.76 \\
\hline Val & 4.72 & 3.61 & 4.91 & 3.95 \\
\hline Met & 0.73 & 0.69 & 0.55 & 0.68 \\
\hline ne & $\mathbf{3 . 1 3}$ & 2.74 & 3.67 & 2.96 \\
\hline Leu & 4.86 & 4.79 & 3.68 & 2.61 \\
\hline Tyr & 2.04 & 1.04 & 0.76 & 0.90 \\
\hline Phe & 2.10 & 2.52 & 2.35 & 1.05 \\
\hline His & 3.63 & 3.06 & 3.32 & 3.31 \\
\hline Lys & 5.81 & 4.00 & 3.41 & $\mathbf{3 . 5 2}$ \\
\hline Arg & $\mathbf{3 . 5 1}$ & 2.30 & $\mathbf{3 . 7 1}$ & 2.56 \\
\hline \multicolumn{5}{|l|}{ Half-cystine } \\
\hline no reduction & 3.71 & n.d. * & - & - \\
\hline reduction & - & - & - & - \\
\hline \multicolumn{5}{|c|}{ Carboxymethylcysteine } \\
\hline no reduction & - & n.d. & - & - \\
\hline reduction & 4.22 & 1.20 & 3.84 & 1.30 \\
\hline
\end{tabular}

* n.d., not determined. 
ine residues were determined by alkylation, with or without prior reduction, of both glycoproteins. From Table II can be concluded that all cysteine residues present were involved in disulfide bonds, since no carboxymethylcysteine was found in unreduced glycoproteins 1 and 2.

\section{Hemagglutination inhibition assay}

Many secretory glycoproteins contain carbohydrate chains, which possess blood-group activity. The chemical structure of the responsible blood-group substances (A, B, H., Le $e^{a}$ and $L e^{b}$, all of which are carbohydrate chains) is well known (e.g. reviewed by Sharon [23]). So, the demonstration of bloodgroup activity in a glycoprotein at least reveals some structural aspects of its carbohydrate side chains. Therefore we looked for blood-group activity in rat gastric glycoproteins 1 and 2 , by studying the inhibitory effect of reduced glycoproteins on the agglutination of $\mathrm{A}$ and $\mathrm{B}$ red cells by anti-A and anti-B serum (Table III). In view of the different fucose content of the glycoproteins we also investigated the presence of $\mathrm{Le}^{\mathrm{b}}$ activity.

As glycoprotein 1 clearly inhibited agglutination of A red cells, at all serum dilutions used, it expressed blood-group A activity. No blood-group B or Le ${ }^{b}$ activity was found in glycoprotein 1 . Glycoprotein 2 inhibited red cell agglutination of all specificities tested, but whereas its $A$ and B activity was obviously low, Le ${ }^{\mathrm{b}}$ activity was marked. This was in good agreement with the higher fucose content of glycoprotein 2 compared to that of glycoprotein 1 .

\section{TABLE III}

INHIBITORY EFFECT OF GLYCOPROTEINS 1 AND 2 ON AGGLUTINATION OF HUMAN RED CELLS

The hemagglutination inhibition assay was performed as described in the Methods section. The serum dilution given was the final dilution after addition of the glycoprotein solution or physiological salt. The anti-A or B sera and the anti-Le $e^{b}$ serum were incubated with glycoprotein concentrations of 1 and $3 \mathrm{mg} /$ $\mathrm{ml}$, respectively. In the positive controls the antisera were incubated with physiological salt solution instead of gly coprotein. In the negative controls only glycoprotein and no serum was added to the red cells.

\begin{tabular}{|c|c|c|c|c|c|c|}
\hline \multirow{4}{*}{$\begin{array}{l}\text { Blood group of } \\
\text { red cells }\end{array}$} & \multicolumn{2}{|l|}{ Test serum } & \multicolumn{4}{|c|}{ Agglutination } \\
\hline & \multirow[t]{3}{*}{ Specificity } & \multirow[t]{3}{*}{ Dilution } & \multirow{2}{*}{\multicolumn{2}{|c|}{$\begin{array}{l}\text { Test serum } \\
\text { incubated with } \\
\text { glycoprotein }\end{array}$}} & \multicolumn{2}{|c|}{ Control } \\
\hline & & & & & + & - \\
\hline & & & 1 & 2 & & \\
\hline \multirow[t]{4}{*}{$\mathbf{A}$} & anti-A & $1: 16$ & + & + & ++++ & - \\
\hline & & $1: 32$ & - & + & ++ & - \\
\hline & & $1: 64$ & - & + & + & - \\
\hline & & $1: 128$ & - & - & + & - \\
\hline \multirow[t]{4}{*}{$\mathbf{B}$} & anti-B & $1: 16$ & +++ & ++ & +++ & - \\
\hline & & $1: 32$ & ++ & + & ++ & - \\
\hline & & $1: 64$ & ++ & - & ++ & - \\
\hline & & $1: 128$ & + & - & + & - \\
\hline \multirow[t]{3}{*}{$\mathbf{L e}^{\mathbf{b}}$} & anti-Le ${ }^{b}$ & $1: 2$ & ++ & - & ++ & - \\
\hline & & $1: 4$ & + & - & + & - \\
\hline & & $1: 8$ & + & - & + & - \\
\hline
\end{tabular}




\section{Discussion}

The present paper describes the partial characterization of the glycoproteins, that constitute the mucus layer in the rat stomach. Part of the glycoproteins, that of homogenate fraction I, could be isolated directly, but a large amount, from homogenate fraction II, only became accessible for isolation when treated with 2-mercaptoethanol. The glycoproteins were purified by $\mathrm{CsCl}$ density gradient centrifugation. This procedure yielded a glycoprotein fraction, practically devoid of non-covalently bound protein. However, a very small amount of contaminating protein, just measurable by the Lowry method and accounting for less than $0.5 \%$ by weight of the freeze-dried reduced glycoproteins, remained present. This 'contamination' which could be visualized by electrophoresis of the glycoprotein fraction on 7-15\% polyacrylamide gradient gels, was removed completely by a second $\mathrm{CsCl}$ gradient centrifugation of the glycoprotein. Apparently these proteins are tightly associated with the mucus and perhaps some of them may have a linking function between the glycoprotein molecules, shown by Roberts [24] for bronchial mucus.

Homogenate fractions I and II both contained the glycoproteins 1 and 2, with the same respective physicochemical properties in the reduced state. Gel filtration experiments proved that glycoproteins 1 and 2 from the unreduced homogenate fraction I are larger than the reduced glycoproteins. Apparently, as also became clear from the carboxymethylcysteine determination, in the unreduced molecules are present disulfide bonds which are cleaved upon reduction. A glycoprotein molecule build up by monomers held together by S-5 bonds would agree with the conclusions of Starkey et al. [1] about the structure of pig gastric mucous glycoprotein.

The $s_{20, w}^{0}$ value of the reduced glycoproteins $1(15.7 \mathrm{~S})$ and $2(11.6 \mathrm{~S})$ were in the same order of magnitude as those of the subunits from pig gastric mucous glycoprotein, obtained after reduction [15] and of rat goblet cell mucin [25], an unreduced molecule lacking a subunit structure.

Glycoproteins 1 and 2 have a chemical composition very well comparable with that of other known mucous glycoproteins. They contain much threonine and serine, which is characteristic for this type of molecule. The relative lower threonine and serine content in the glycoproteins from homogenate fraction I was probably due to a somewhat greater amount of contaminating protein in these unreduced fractions. As was found for pig [1] and dog [2,3], gastric mucus threonine content in glycoproteins 1 and 2 was slightly higher than that of serine. The amount of glycine, glutamic acid and aspartic acid was quite high, as in pig gastric mucus [1]. In both glycoproteins proline was present in remarkably low concentrations. In both glycoproteins extremely low amounts of sialic acid were found. It is possible that neuraminidase activity is present in the stomach wall - as was shown in pig gastric mucus [26] - which liberates this sugar. Anyway, the amount of sialic acid in the original molecules has to be very small, since the homogenates were always kept in conditions unsuitable for neuraminidase activity. The higher sulfate content of glycoprotein 2 compared to glycoprotein 1 might be responsible for its higher density, its faster migration during gel electrophoresis and its lower stainability by periodic acid-Schiff. Pamer et al. [2] also found a reduced stainability of sulfated glyco- 
proteins for this reagent. Based on earlier reports concerning blood-groups in rats $[27,28]$, Wistar rats were supposed to have blood-group $A$ activity. From our results of the hemagglutination inhibition assay we conclude that the rats are secretors of this blood group, at least as far as glycoprotein 1 is concerned. Blood-group activity $\mathrm{A}$ of this major component is consistent with its galactosamine content. $50 \%$ of its galactosamine residues are available for end-group positions with blood-group A activity, provided that every threonine and serine is bound to galactosamine. In this case the sugar chains of glycoprotein 1 would have a length of about 18 residues, as the composing sugars galactosamine (bloodgroup A), galactose, fucose, glucosamine and galactosamine (bound to serine or threonine) then show molar proportions $1: 6: 4: 6: 1$. The number of galactosamine residues in glycoprotein 2 does not exceed the total number of serine and threonine residues, but we found some blood-group A activity, which indicates that not every serine and threonine is bound to galactosamine. This would leave galactosamine residues for constituting bloodgroup $A$. The lower carbohydrate/protein ratio of glycoprotein 2 and its chromatographic behavior, indicating a smaller molecular size than glycoprotein 1 , would be in favor of this supposition. The finding of some blood-group B activity, too, was unexpected.

It takes further experimentation to find out the origin of both glycoproteins. Wattel et al. [29] found that mucous cells in deeper parts of the isthmus of gastric pits, which are young cells, contain and incorporate more sulfate than the more superficial mucous cells of the stomach wall. It is quite possible that glycoprotein 1 is a product of mature mucus cells, whereas glycoprotein 2 represents the mucus of younger cells which might lose their sulfo- and fucosyl transferases on maturation. The two glycoproteins may also be products of cells lying in different regions - e.g., fundus and cardia - of the stomach wall. Work is in progress to elucidate this problem.

\section{Acknowledgements}

The authors wish to thank Mr. G.J. Gerwig (Laboratory of Organic Chemistry), Mr. J. Suurmond (van 't Hoff Laboratory), Dr. W.W. de Jong and coworkers and Dr. H.M. Verhey and coworkers (Biochemical Laboratories of Nijmegen and Utrecht) for performing gas-liquid chromatography, sedimentation velocity experiments and amino acid analyses, respectively. The investigations were supported in part by the Foundation for Medical Research, FUNGO, which is subsidized by the Dutch Organization for Advancement of Pure Research (ZWO).

\section{References}

1 Starkey, B.J., Snary, D. and Allen, A. (1974) Biochem. J. 141, 633-639

2 Pamer, 'T., Glass, G.B.J. and Horowitz, M.I. (1968) Biochemistry 7, no $113821-3829$

3 Wousson-Colle, M.C., Rasinsky, C. and de Graef, J. (1975) Biol. Gastroenterol. (Paris) 8, 275-282

4 Schrager, J. and Oates, M.D.G. (1974) Biochim. Biophys. Acta 373, 183-195

5 Kramer, M.F. and Geuze, J.J. (1977) J. Cell Biol. 73, 533-547

6 Strous, G.J.A.M. and Kramer, M.F. (1976) Biochim. Biophys. Acta 451, 201-211

7 Creeth, J.M. and Denborough, M.A. (1970) Biochem. J. 117, 879-891

8 Creeth, J.M., Bhaskar, R., Horton, J.R., Das, I., Lopez-Vidriero, M. and Reid, L. (1977) Biochem. J. $167,557-569$ 
9 Gelman, R.A. and Vered, J. (1976) Biochim. Biophys. Acta 427, 627-633

10 Peacock, A.C. and Dingman, W. (1968) Biochemistry 2, 668-674

11 Laemmli, U.K. (1970) Nature 227, 680-685

12 Holden, K.G., Yim, N.C.F., Griggs, L.J. and Weisbach, J.A. (1971) Biochemistry 10, No. 16, 3105-3109

13 McGuckin, W.F. and McKenzie, B.F. (1958) Clin. Chem. 4, no 6, 467-483

14 Press, E.M., Piggot, P.J. and Porter, R.R. (1966( Biochem. J. 99, 356-366

15 Scawen, M. and Allen, A. (1975) Biochem. Soc. Trans. 3, 1107-1109

16 Lowry, O.H., Rosebrough, N.J., Farr, A.L. and Randall, R.J. (1951) J. Biol. Chem. 193, 265-275

17 Francois, C., Marshall, R.D. and Neuberger, A. (1962) Biochem. J. 83, 335-341

18 Warren, L. (1959) J. Biol. Chem, 234, 1971-1975

19 Dodgson, K.S. and Price, R.C. (1962) Biochem. J. 84, 106

20 Kamerling, F.P., Gerwig, G.J., Vliegenthart, J.F.G. and Clamp, J.R. (1975) Biochem. J. 151, $491-495$

21 Boorman, K.E: and Dodd, B.E. (1966) An Introduction to Bloodgroup Serology, 3rd edn., pp. 61-66, Churchill Ltd., London

22 Jabbal, J., Forstner, G.G., Forstner, J. and Kells, D.I.C. (1975) Anal. Biochem. 69, 558-571

23 Sharon, N. (1975) Complex Carbohydrates, Their Chemistry, Biosynthesis and Functions, pp. 215-233, Addison-Wesley, Reading, MA

24 Roberts, G.P. (1976) Arch. Biochim. Biophys. 173, 528-537

25 Forstner, J.F., Jabbal, J. and Forstner, G.G. (1973) Can. J. Biochem. 51, 1154-1166

26 Allen, A. and Staxkey, B.J. (1974) Biochim. Biophys. Acta 338, 364-368

27 Burhoe, S.O. (1947) Proc. Natl. Acad. Sci. U.S.A. 32, 102-109

28 Hagemann, E. (1960) Ratte und Maus, p. 84, Walter de Gruyter and Co., Berlin

29 Wattel, W., Geuze, J.J. and Rooij, D.G. (1977) Cell Tiss. Res. 176, 445-462 